2 A modern iron isotope perspective on the redox evolution of

\title{
ancient oceans
}

4 Silke Severmann, Timothy W. Lyons, Ariel Anbar, James McManus \& Gwyneth Gordon

5

\section{Materials and methods}

1) Sample descriptions

The samples used in this study were collected during the $1988 R / V$ Knorr Black Sea cruise. The exact locations, sedimentology and geochemistry are described in detail elsewhere (Lyons, 1991; Lyons and Berner, 1992; Lyons et al., 1993; Anderson et al., 1994; Canfield et al., 1996; Lyons, 1997; Hurtgen et al., 1999). Cores from the central euxinic basin (stations 9 and 14,>2000 m) consist entirely of microlaminated, coccolithrich Unit 1 mud [using the nomenclature of Ross et al. ( 1970)]. Organic carbon and calcium carbonate concentrations in these euxinic sediment average $5.3 \pm 1.0$ and $52.5 \pm 11.3( \pm 1 \mathrm{~s})$ wt. $\%$, respectively. Pyrites in this unit are present dominantly as finegrained framboidal aggregates, which is indicates that they formed syngenetically in the water column (Wilkin and Arthur, 2001).

Stations 3, 4, 16, and 17 were on the shallow oxic shelf, where sediments are characterized by high degrees of bioturbation. Below the surface interval, organic carbon and calcium carbonate concentrations at the four shallow stations collectively average $1.3 \pm 0.4$ and $20.1 \pm 5.3$ wt.\%, respectively. The shallower Black Sea sediments contain an increasing proportion of fine-grained euhedral pyrite, which is more typical of diagenetic pyrite formation within the sediments (Wilkin and Arthur, 2001). Sedimentation rates for Unit 1 sediments have been estimated as roughly 15 to $20 \mathrm{~cm} / \mathrm{kyr}$ (Calvert and Karlin, 1991; Crusius and Anderson, 1992; Arthur et al., 1994; Jones and Gagnon, 1994). Rates at stations 3, 16 and 17 range between 60 and $90 \mathrm{~cm} / \mathrm{kyr}$ (Anderson et al., 1994; data are unavailable for Station 4). 


\section{2) Sample preparation and analysis}

30 For analysis of total iron isotope compositions, $\sim 0.1 \mathrm{~g}$ of dried sediment was fully

31 dissolved using a mixture of $\mathrm{HNO}_{3}, \mathrm{HClO}_{3}$ and $\mathrm{HF}$. For determination of pyrite isotope

32 composition we used a chemical leaching procedure modified after Huerta-Diaz and

33 Morse (1992). Briefly, $\sim 0.5 \mathrm{~g}$ of dry sediment was extracted in concentrated boiling $\mathrm{HCl}$

34 for $1 \mathrm{~min}$. The residue was treated with two sequential HF extractions $(30 \mathrm{ml} 10 \mathrm{M}$ HF for

$351 \mathrm{hr}$, then $30 \mathrm{ml} 10 \mathrm{M} \mathrm{HF}$ for $16 \mathrm{hrs}$ ) to dissolve any remaining silicate phases. The only

36 significant iron phase remaining after this treatment is pyrite, which was extracted in 10

$37 \mathrm{ml}$ of concentrated $\mathrm{HNO}_{3}$ for $2 \mathrm{hrs}$. All extractions were performed at room temperature

38 under constant shaking. Chemically extracted pyrite-Fe was dried down repeatedly in

39 concentrated $\mathrm{HNO}_{3}$ and $\mathrm{H}_{2} \mathrm{O}_{2}$ to break down any residual organic carbon. Dry residue

40 was dissolved in $7 \mathrm{M} \mathrm{HCl}$, and $\sim 100 \mu \mathrm{g}$ of iron was purified on Bio-Rad AG1X8 anion

41 resin $(\sim 250 \mu 1$ volume $)$ following the procedure of Beard et al. (2003). Column yields

42 were carefully monitored by Ferrozine analysis of each sample before and after chemical

43 processing, and only samples that had $\geq 95 \%$ recovery were used for iron isotope analysis.

44 Iron isotope analysis was performed on a ThermoFinnigan Neptune multi-

45 collector inductively coupled plasma mass-spectrometer (MC-ICP-MS) at Arizona State

46 University, following the method of Arnold et al. (2004). Samples were introduced as 2

47 ppm or 3 ppm solutions through a desolvating nebulizer. The analysis was performed in

48 medium mass resolution mode (mass resolving power of 8000-9000). Mass bias during

49 the analysis was corrected by using a $\mathrm{Cu}$ elemental spike, which was added to the

50 purified samples to a concentration matching that of the Fe concentration. In addition,

51 sample isotope ratios were normalized to the average of two bracketing standards as an

52 additional correction for instrumental mass discrimination. ${ }^{53} \mathrm{Cr},{ }^{54} \mathrm{Fe},{ }^{56} \mathrm{Fe},{ }^{57} \mathrm{Fe},{ }^{58} \mathrm{Fe}$,

$53{ }^{60} \mathrm{Ni},{ }^{63} \mathrm{Cu}$ and ${ }^{65} \mathrm{Cu}$ were measured in dynamic mode, where masses 53 to 60 were

54 measured during the first integration and the two $\mathrm{Cu}$ isotopes were measured during the

55 second integration.

56 Several standard reference materials of known isotope composition, including

57 IRMM-014, were measured routinely for each sample batch. In addition, we measured

58 gravimetric standards, which were prepared by adding a known amount of enriched ${ }^{54} \mathrm{Fe}$

59 tracer (97.7\% purity, Oak Ridge National Lab) to IRMM-014 standard. Of the 64 samples 
60 analyzed in this study, 15 were processed through duplicate chemical treatment, including 61 sample dissolution or pyrite-Fe extraction and chromatographic extraction. Data are 62 reported in per mil (\%o) $\delta$ notation using the ${ }^{56} \mathrm{Fe} /{ }^{54} \mathrm{Fe}$ sample ratio relative to the average 63 of igneous rocks $\left(\delta^{56} \mathrm{Fe}\right)$, which have a $\delta^{56} \mathrm{Fe}$ of $0.00 \pm 0.05 \%$ (Beard et al., 2003). On 64 this scale, the IRMM-014 standard has $\delta^{56} \mathrm{Fe}=-0.09 \%$. Replicate analyses were made 65 on different days, and errors for samples with $\geq 2$ repeat analyses are reported as two 66 standard deviations (2-SD). The average external 2-SD reproducibility, as determined by 67 duplicate analysis via re-processing of several powdered samples through chemistry, is $68 \pm 0.06 \%$ for $\delta^{56} \mathrm{Fe}$ and $\pm 0.07 \%$ for $\delta^{57} \mathrm{Fe}$.

69 The iron isotope fractionation between coexisting phases A and B is described by

$70 \quad \Delta^{56} \mathrm{Fe}_{\mathrm{A}-\mathrm{B}}=\delta^{56} \mathrm{Fe}_{\mathrm{A}}-\delta^{56} \mathrm{Fe}_{\mathrm{B}} \approx 10^{3} \ln \alpha_{\mathrm{A}-\mathrm{B}}$,

71 where $\alpha_{\mathrm{A}-\mathrm{B}}$ is the isotope fractionation factor in terms of ${ }^{56} \mathrm{Fe} /{ }^{54} \mathrm{Fe}$ ratios.

72 The isotope composition of the benthic export flux $\delta^{56} \mathrm{Fe}_{\mathrm{Ex}}$ may be calculated

73 using the iron isotope composition of either $\mathrm{Fe}_{\mathrm{T}}$ or $\mathrm{Fe}_{\mathrm{Py}}$ :

$74 \quad \delta^{56} \mathrm{Fe}_{\mathrm{Ex}}=\left(\delta^{56} \mathrm{Fe}_{\mathrm{T}} *\left[\mathrm{Fe}_{\mathrm{T}}\right]\right) /\left[\mathrm{Fe}_{\mathrm{Ex}}\right]$

75 or

$76 \quad \delta^{56} \mathrm{Fe}_{\mathrm{Ex}}=\left(\delta^{56} \mathrm{Fe}_{\mathrm{Py}} *\left[\mathrm{Fe}_{\mathrm{Py}}\right]\right) /\left[\mathrm{Fe}_{\mathrm{Ex}}\right]$,

77 where $\left[\mathrm{Fe}_{\mathrm{Ex}}\right]$ denote concentrations of the individual iron pools. Benthic export iron flux

78 is assumed to be quantitatively converted to pyrite, and concentrations of the exported

79 iron component in the sediments are calculated as

$80 \quad\left[\mathrm{Fe}_{\mathrm{Ex}}\right]=\left[\mathrm{Fe}_{\mathrm{T}]^{-}}[\mathrm{Al}]^{*} 0.6\right.$

81 where 0.6 is the $\mathrm{Fe}_{\mathrm{T}} / \mathrm{Al}$ ratio for the lithogenic baseline. This ratio represents the highest

82 ratio measured for sediments from the oxic shelf (Station 17, mean $\mathrm{Fe}_{\mathrm{T}} / \mathrm{Al}=0.60$, see

83 Table $\mathrm{S} 1$ ) and is higher than the commonly used $\mathrm{Fe}_{\mathrm{T}} / \mathrm{Al}$ ratio for average shale of 0.5

84 (Taylor and McLennan, 1985). Shuttling of reactive Fe from the shelf sediments to the 85 deep basin causes a decrease of the $\mathrm{Fe}_{\mathrm{T}} / \mathrm{Al}$ ratio, suggesting that our elevated ratios are 86 not due to post-depositional modification of the detrital material, but rather that they 
87 reflect a local lithogenic $\mathrm{Fe}_{\mathrm{T}} / \mathrm{Al}$ baseline for the Black Sea that deviates from the

88 generally accepted global average (Lyons and Severmann, 2006). Probably the best

89 approach to derive an estimate of the $\mathrm{Fe}_{\mathrm{T}} / \mathrm{Al}$ baseline would be to measure the

90 composition of particles from the zone of estuarine mixing, since riverine particles

91 undergo some modification during passage through the estuary (Poulton and Raiswell,

92 2005). In the absence of a direct measure of the $\mathrm{Fe}_{\mathrm{T}} / \mathrm{Al}$ ratio for the local terrestrial

93 particulate input, we assume that our highest measured sediment $\mathrm{Fe}_{\mathrm{T}} / \mathrm{Al}$ ratios best

94 represent a lithogenic baseline value for the Black Sea, although we recognize that this is

95 not ideal. We note, however, that the choice of the $\mathrm{Fe}_{\mathrm{T}} / \mathrm{Al}$ baseline as well as its isotope

96 composition does not affect our principal observation, which is the systematic decrease in

97 iron isotope compositions from the shelf sediments to the deep basin sediments and their

98 inverse relationship with $\mathrm{Fe}_{\mathrm{T}} / \mathrm{Al}$ ratios (Fig. 3). 
101

102

103

104

105

106

107

108

109

110

111

112

113

114

115

116

117

118

119

120

121

122

123

124

125

126

127

128

129

130

131

132

133

134

135

136

137

138

139

140

141

142

143

144

Anderson R. F., Lyons T. W., and Cowie G. L. (1994) Sedimentary record of a shoaling of the oxic/anoxic interface in the Black Sea. Mar. Geol. 116, 373-384.

Arnold G. L., Weyer S., and Anbar A. D. (2004) Fe isotope variations in natural materials using high mass resolution multiple collector ICPMS. Anal. Chem. 76, 322-327.

Arthur M. A., Dean W. E., Neff E. D., Hay B. J., King G. M., and Jones A. D. (1994) Varve calibrated records of carbonate and organic carbon accumulation over the last 2000 years in the Black Sea. Global Biogeochem. Cycles 8, 195-217.

Beard B. L., Johnson C. M., Skulan J. L., Nealson K. H., Sun H., and Cox L. (2003) Application of $\mathrm{Fe}$ isotopes to tracing the geochemical and biochemical cycling of Fe. Chem. Geol. 195, 87-117.

Calvert S. E. and Karlin R. E. (1991) Relationships between sulphur, organic carbon, and iron in the modern sediments of the Black Sea. Geochim. Cosmochim. Acta 55, 2483-2490.

Canfield D. E., Lyons T. W., and Raiswell R. (1996) A model for iron deposition to euxinic Black Sea sediments. Am. J. Sci. 296, 818-834.

Crusius J. and Anderson R. F. (1992) Inconsistencies in accumulation rates of Black Sea sediments inferred from records of laminae and ${ }^{210} \mathrm{~Pb}$. Paleoceanography 7, 215227.

Huerta-Diaz M. A. and Morse J. W. (1992) Pyritization of trace metals in anoxic marine sediments. Geochim. Cosmochim. Acta 56, 2681-2702.

Hurtgen M. T., Lyons T. W., Ingall E. D., and Cruse A. M. (1999) Anomalous enrichments of iron monosulfide in euxinic marine sediments and the role of $\mathrm{H}_{2} \mathrm{~S}$ in iron sulfide transformations; examples from Effingham Inlet, Orca Basin, and the Black Sea. Am. J. Sci. 299, 556-588.

Jones G. A. and Gagnon A. R. (1994) Radiocarbon chronology of Black Sea sediments. Deep-Sea Res. 41, 531-557.

Lyons T. W. (1991) Upper Holocene sediments of the Black Sea: Summary of Leg 4 boxcores (1988 Black Sea Oceanographic expedition). In Black Sea Oceanography (ed. E. Izdar and J. W. Murray), pp. 401-441. Kluwer.

Lyons T. W. (1997) Sulfur isotope trends and pathways of iron sulfide formation in the upper Holocene sediments of the anoxic Black Sea. Geochim. Cosmochim. Acta 61, 3367-3382.

Lyons T. W. and Berner R. A. (1992) Carbon-sulfur-iron systematics of the uppermost deep-water sediments of the Black Sea. Chem. Geol. 99, 1-27.

Lyons T. W. and Severmann S. (2006) A critical look at iron paleoredox proxies based on new insights from modern euxinic marine basins. Geochim. Cosmochim. Acta 70, 5698-5722.

Lyons T. W., Berner R. A., and Anderson R. F. (1993) Evidence for large pre-industrial permutations of Black Sea chemocline. Nature 365, 538-540.

Poulton S. W. and Raiswell R. (2005) Chemical and physical characteristics of iron oxides in riverine and glacial meltwater sediments. Chem. Geol. 218, 203-221.

Ross D. A., Degens E. T., and Macllvaine J. (1970) Black Sea: recent sedimentary history. Science 170, 163-165. 
145 Taylor S. R. and McLennan S. M. (1985) The Continental Crust: Its Composition and 146 Evolution. Blackwell.

147 Wilkin R. T. and Arthur M. A. (2001) Variations in pyrite texture, sulfur isotope 148 compositions, and iron systematics in the Black Sea: Evidence for the late 149

150 Pleistocene to Holocene excursions of the $\mathrm{O}_{2}-\mathrm{H}_{2} \mathrm{~S}$ redox transitions. Geochim. 151 Cosmochim. Acta 65, 1399-1416. 